\title{
Oxidation of primary aliphatic alcohols by Acetobacterium carbinolicum sp. nov., a homoacetogenic anaerobe
}

\author{
Barbara Eichler and Bernhard Schink \\ Fakultät für Biologie, Universität Konstanz, Postfach 5560, D-7750 Konstanz, Federal Republic of Germany
}

\begin{abstract}
Four strains of new homoacetogenic bacteria were enriched and isolated from freshwater sediments and sludge with ethanol, propanol, 1,2-propanediol, or 1,2-butanediol as substrates. All strains were Gram-positive nonsporeforming rods and grew well in carbonate-buffered defined media under obligately anaerobic conditions. Optimal growth occurred at $27^{\circ} \mathrm{C}$ around $\mathrm{pH}$ 7.0. $\mathrm{H}_{2} / \mathrm{CO}_{2}$, primary aliphatic alcohols $\mathrm{C}_{1}-\mathrm{C}_{5}$, glucose, fructose, lactate, pyruvate, ethylene glycol, 1,2-propanediol, 2,3-butanediol, acetoin, glycerol, and methyl groups of methoxylated benzoate derivates and betaine were fermented to acetate or, in case of primary alcohols $\mathrm{C}_{3}-\mathrm{C}_{5}$ and 1,2-propanediol, to acetate and the respective fatty acid. In coculture with methanogens methane was formed, probably due to interspecies hydrogen transfer. Strain WoProp1 is described as a new species, Acetobacterium carbinolicum. It had a DNA base composition of $38.5 \pm 1.0 \%$ guanine plus cytosine, and contained murein of crosslinkage type $\mathrm{B}$ similar to $A$. woodii.
\end{abstract}

Key words: Acetobacterium carbinolicum species description - Homoacetogenic fermentations - Incomplete oxidation - Anaerobic degradation - Alcohol oxidation Diols - Syntrophy - Interspecies hydrogen transfer

Primary aliphatic alcohols are formed during anaerobic degradation of organic matter. A variety of facultatively and obligately anaerobic bacteria ferments carbohydrates to form ethanol, propanol, and butanol among other fermentation products. Under anaerobic conditions, alcohols are oxidized to the respective fatty acid with concomitant reduction of external electron acceptors, e.g. sulfate (Postgate and Campbell 1966). In the absence of external electron acceptors, electrons derived from alcohol oxidation can be released as molecular hydrogen which is used by hydrogen-oxidizing bacteria, e.g. methanogenic bacteria. Methanobacillus omelianskii is such a syntrophic association of two bacteria which converts ethanol to acetate and methane (Barker 1941; Bryant et al. 1967).

A third way of degradation of primary alcohols is the fermentation to fatty acids as reduced end products. Clostridium kluyveri ferments ethanol with acetate to butyrate (Bornstein and Barker 1948). The sulfate-reducing bacterium Desulfobulbus propionicus ferments ethanol in the

Offprint requests to: $\mathrm{B}$. Schink absence of sulfate to acetate and propionate using carbon dioxide as electron acceptor (Laanbroek et al. 1982). A similar fermentation pattern was reported for an unidentified anaerobic bacterium (Samain et al. 1982) and for Pelobacter propionicus (Schink 1984a).

Clostridium aceticum oxidizes ethanol to acetate and uses carbon dioxide as electron acceptor to form further acetate (Wieringa 1940; Braun et al. 1981), according to the equation:

$2 \mathrm{CH}_{3} \mathrm{CH}_{2} \mathrm{OH}+2 \mathrm{HCO}_{3}^{-} \rightarrow 3 \mathrm{CH}_{3} \mathrm{COO}^{-}+\mathrm{H}^{+}+2 \mathrm{H}_{2} \mathrm{O}$.

In the present study, a new anaerobic bacterium physiologically similar to $C$. aceticum is described which ferments primary aliphatic alcohols and bicarbonate to the respective fatty acids and acetate. Since the new isolate is cytologically similar to Acetobacterium woodii (Balch et al. 1977), however, differs from this species by its ability to oxidize primary aliphatic alcohols, it is described as a new species, $\boldsymbol{A}$. carbinolicum.

\section{Materials and methods}

\section{Sources of organisms}

Four strains were enriched and isolated in pure culture from freshwater mud samples:

Strain WoProp1 and strain AS1.2Bd1 from black anoxic mud of a creek and a ditch, respectively, near Konstanz, FRG.

Strain Gö1.2Pd1 from anoxic digestor sludge of municipal sewage plants at Göttingen, FRG.

Strain OttEtOH1 from black anoxic mud of a creek near Hannover, FRG.

Methanospirillum hungatei $\mathrm{M} 1 \mathrm{~h}$ was isolated from digested sludge of the sewage plant at Göttingen, FRG, and cultivated on freshwater medium with $10 \mathrm{mmol} / 1$ acetate under $\mathrm{H}_{2} / \mathrm{CO}_{2}$ mixture $(80 \% / 20 \%)$.

Acetobacterium woodii strain NZva16 was provided by A. Tschech, University of Konstanz.

\section{Media and growth conditions}

All procedures for cultivation and isolation as well as all methods for analysis of metabolic products were exactly as described in earlier papers (Widdel and Pfennig 1981; Schink and Pfennig 1982; Schink 1984a). The mineral medium for enrichment and further cultivation contained $30 \mathrm{mM}$ 


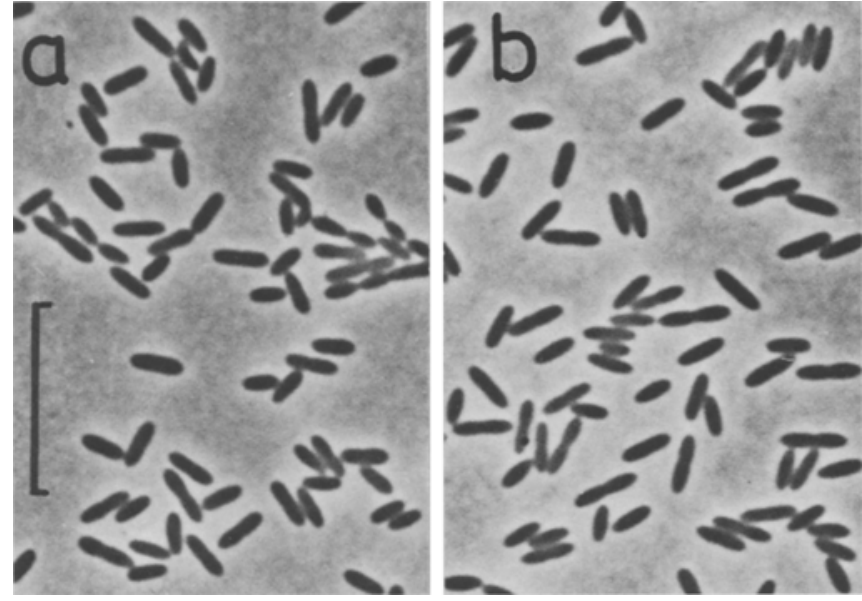

Fig. 1a,b. Phase-contrast photomicrographs of Acetobacterium carbinolicum. a Strain WoProp1 enriched with propanol. b Strain OttEtOH1 enriched with ethanol. Bar $=10 \mu \mathrm{m}$

sodium bicarbonate as buffer, sodium sulfide as reducing agent, and the new trace element solution SL9 (Tschech and Pfennig 1984). The $\mathrm{pH}$ was 7.0-7.2. Growth experiments were carried out at $28^{\circ} \mathrm{C}$. For isolation of pure cultures, the agar shake culture method (Pfennig 1978) was applied. All chemicals used were of reagent grade quality.

\section{Results}

\section{Enrichment and isolation}

Enrichment cultures with freshwater medium $(50 \mathrm{ml})$ containing $10 \mathrm{mmol} / 1$ of either ethanol, propanol, 1,2-propanediol, or 1,2-butanediol as substrates were inoculated with $5 \mathrm{ml}$ freshwater mud samples from different sources. Methane production was observed after 1-2 weeks of incubation. In subcultures, gas production was not detectable any more after the fourth transfer. Isolation of pure cultures was carried out in agar shake series using the same substrate as in the enrichment cultures. Bacteria formed white to yellowish lens-shaped colonies in the agar. Colonies were resuspended in mineral medium and again purified in agar shake series. Purity was checked by microscopical control and by growth tests in AC medium in which only the isolated cell types could be observed. Finally four strains were chosen for further characterization.

\section{Cytological properties}

All strains isolated were rods, $0.8-1.3 \times 1.8-3.5 \mu \mathrm{m}$ in size, with slightly pointed ends. Cells tended to form chains of two or three cells (Fig. 1). Cells of all strains were motile, but lost motility in ageing cultures. All strains stained Grampositive. Electron microscopic examination of ultrathin sections of two strains showed typical Gram-positive cell wall structures (Fig. 2). The murein chemistry was kindly examined by Prof. Dr. Otto Kandler, München. He detected a B-type murein very similar to that of Acetobacterium woodii (Kandler and Schoberth 1979) with a mol ratio of ornithine:glutamate: serine:alanine of $2: 1: 1: 0.8$. A small part of ornithine was replaced by lysine. None of our strains formed spores neither in defined medium nor in special

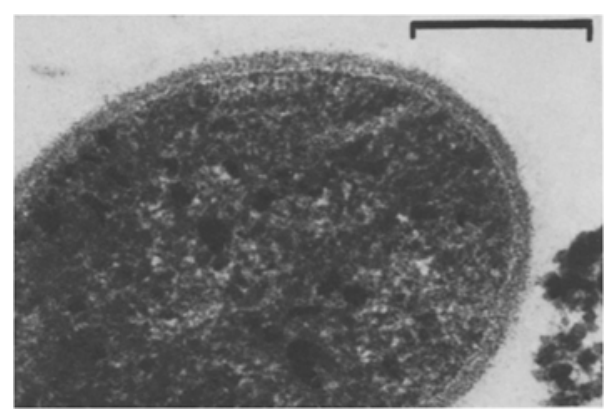

Fig. 2. Electron micrograph of ultrathin section of Acetobacterium carbinolicum strain WoProp1. Bar $=0.2 \mu \mathrm{m}$

sporulation medium (Hollaus and Sleytr 1972). Enrichment cultures with ethanol and pasteurized mud samples from four sources did not show any growth after 8 weeks of incubation. The guanine plus cytosine content of the DNA was determined with two strains and Escherichia coli strain K12 (DSM 498) as reference. It was $38.5 \pm 1.0 \mathrm{~mol} \%$ with strain WoProp1 and $41.3 \pm 1.0 \mathrm{~mol} \%$ with strain OttEtOH1.

No cytochromes could be detected in redox difference spectra of crude cell extracts or membrane preparations.

\section{Physiology}

All strains grew well in freshwater medium containing up to $0.72 \%(\mathrm{w} / \mathrm{v}) \mathrm{NaCl}$ and $0.15 \%(\mathrm{w} / \mathrm{v}) \mathrm{MgCl}_{2} \cdot 6 \mathrm{H}_{2} \mathrm{O}$; no growth occurred in saltwater medium $[2.0 \%(\mathrm{w} / \mathrm{v}) \mathrm{NaCl}$, $0.3 \%(\mathrm{w} / \mathrm{v}) \mathrm{MgCl}_{2} \cdot 6 \mathrm{H}_{2} \mathrm{O}$ ]. Phosphate inhibited growth slightly at $\geq 50 \mathrm{mmol} / 1$ concentration. The strains grew well in defined medium with vitamin and trace element solutions. Yeast extract was not required for growth, but all strains grew faster and to higher cell densities in the presence of $0.05 \%$ yeast extract.

Methanol, ethanol, propanol, butanol, pentanol, several diols, acetoin, glycerol, malate, pyruvate, glucose, and fructose were used as substrates. Autotrophic growth was found on formate and hydrogen/carbon dioxide. Methoxylated derivates of benzoic acid were demethylated to the respective phenols. Neither cinnamic acid nor caffeic acid was reduced to phenylpropionic acids. Neither nitrate, sulfate, thiosulfate, nor sulfur was reduced during degradation of primary alcohols. The results of all substrate tests are summarized in Table 1. Degradation products of primary alcohols and 1,2-diols were the corresponding fatty acids and acetate. With all other substrates, acetate was the only fermentation product.

The growth curve (Fig. 3) illustrates the correlation of growth, ethanol decomposition, and acetate formation by strain WoProp1. Optimal growth $\left(\mu=0.087 \mathrm{~h}^{-1}\right.$; $t_{\mathrm{d}}=8.0 \mathrm{~h}$ ) occurred at $27^{\circ} \mathrm{C}$, the temperature limits were $15^{\circ} \mathrm{C}$ and $40^{\circ} \mathrm{C}$. The $\mathrm{pH}$-optimum was at $\mathrm{pH} 7.0-7.2$; the $\mathrm{pH}$ limits were $\mathrm{pH} 6.0$ and 8.0 .

\section{Growth yields and stoichiometry}

The stoichiometry of substrate utilization and product formation was measured with all strains. The results obtained with strain WoProp1 are presented in Table 2. The amounts of products formed agreed with complete conver- 
sion of the substrates to acetate and other fatty acids accord-

ing to the following equations:

Hydrogen/carbon dioxide:

$4 \mathrm{H}_{2}+2 \mathrm{HCO}_{3}^{-}+\mathrm{H}^{+} \rightarrow \mathrm{CH}_{3} \mathrm{COO}^{-}+4 \mathrm{H}_{2} \mathrm{O}$

Formate:

$4 \mathrm{HCOO}^{-}+\mathrm{H}^{+} \rightarrow \mathrm{CH}_{3} \mathrm{COO}^{-}+2 \mathrm{HCO}_{3}^{-}$

Methanol:

$4 \mathrm{CH}_{3} \mathrm{OH}+2 \mathrm{HCO}_{3}^{-} \rightarrow 3 \mathrm{CH}_{3} \mathrm{COO}^{-}+\mathrm{H}^{+}+4 \mathrm{H}_{2} \mathrm{O}$

Aliphatic alcohols:

$2 \mathrm{R}-\mathrm{CH}_{2} \mathrm{OH}+2 \mathrm{HCO}_{3}^{-} \rightarrow 2 \mathrm{R}-\mathrm{COO}^{-}+\mathrm{CH}_{3} \mathrm{COO}^{-}+\mathrm{H}^{+}+\mathrm{H}_{2} \mathrm{O}$

1,2-Diols:

$4 \mathrm{R}-\mathrm{CHOH}-\mathrm{CH}_{2} \mathrm{OH}+2 \mathrm{HCO}_{3}^{-} \rightarrow 4 \mathrm{R}-\mathrm{CH}_{2} \mathrm{COO}^{-}+\mathrm{CH}_{3} \mathrm{COO}^{-}+3 \mathrm{H}^{+}+4 \mathrm{H}_{2} \mathrm{O}$

2,3-Butanediol:

$4 \mathrm{CH}_{3} \mathrm{CHOH}-\mathrm{CHOH}-\mathrm{CH}_{3}+6 \mathrm{HCO}_{3}^{-} \rightarrow 11 \mathrm{CH}_{3} \mathrm{COO}^{-}+5 \mathrm{H}^{+}+4 \mathrm{H}_{2} \mathrm{O}$

Acetoin:

$2 \mathrm{CH}_{3} \mathrm{CO}-\mathrm{CHOH}-\mathrm{CH}_{3}+2 \mathrm{HCO}_{3}^{-} \rightarrow 5 \mathrm{CH}_{3} \mathrm{COO}^{-}+5 \mathrm{H}^{+}+4 \mathrm{H}_{2} \mathrm{O}$

Glycerol:

$\mathrm{CH}_{3} \mathrm{OH}-\mathrm{CHOH}-\mathrm{CH}_{3} \mathrm{OH}+2 \mathrm{HCO}_{3}^{-} \rightarrow 7 \mathrm{CH}_{3} \mathrm{COO}^{-}+5 \mathrm{H}^{+}+4 \mathrm{H}_{2} \mathrm{O}$

Lactate:

$2 \mathrm{CH}_{3} \mathrm{CHOH}-\mathrm{COO}^{-} \rightarrow 3 \mathrm{CH}_{3} \mathrm{COO}^{-}+\mathrm{H}^{+}$

Pyruvate:

$4 \mathrm{CH}_{3} \mathrm{CO}-\mathrm{COO}^{-}+4 \mathrm{H}_{2} \mathrm{O} \rightarrow 5 \mathrm{CH}_{3} \mathrm{COO}^{-}+2 \mathrm{HCO}_{3}^{-}+\mathrm{H}^{+}$

Hexoses:

$\mathrm{C}_{6} \mathrm{H}_{12} \mathrm{O}_{6} \rightarrow 3 \mathrm{CH}_{3} \mathrm{COO}^{-}+3 \mathrm{H}^{+}$.

Substrate assimilated into cell material was calculated via acetate according to the following equation:

$17 \mathrm{CH}_{3} \mathrm{COO}^{-}+11 \mathrm{H}_{2} \mathrm{O} \rightarrow 8\left(\mathrm{C}_{4} \mathrm{H}_{7} \mathrm{O}_{3}\right)+2 \mathrm{HCO}_{3}^{-}+15 \mathrm{OH}^{-}$.

Growth yields were determined with all strains. Data for strain WoProp1 are listed in Table 2. With other strains basically the same results were obtained.

\section{Effect of hydrogen on alcohol degradation}

In coculture with the hydrogen-consuming Methanospirillum hungatei, strain WoProp1 fermented ethanol, propanol, butanol, and pentanol to the corresponding fatty acids as well as to acetate and hydrogen which was converted by $M$. hungatei to methane (Table 3). During fermentation of butanol and pentanol, more methane was formed than during ethanol and propanol degradation. The fermentation balance can be understood as a combination of the following two equations:
It appears that the ratio of methane over acetate formed was higher with long chain than with short chain alcohols.

Excess hydrogen added to a culture of strain WoProp1 growing on ethanol delayed and inhibited growth considerably (Fig. 4). Analysis of ethanol and hydrogen in the cultures indicated that ethanol rather than hydrogen was the substrate for growth in these cultures.

\section{Discussion}

Physiology

In the present study, new strains of strictly anaerobic bacteria are described which oxidized primary aliphatic alcohols to the corresponding fatty acids and used the resulting reducing equivalents for acetate synthesis from carbon dioxide. 1,2-Diols were oxidized in a similar manner. The strains also grew autotrophically on either formate or hydrogen/carbon dioxide. Sugars, some organic acids, acetoin, 2,3-butanediol and glycerol were converted to acet-

$2 \mathrm{R}-\mathrm{CH}_{2} \mathrm{OH}+2 \mathrm{HCO}_{3}^{-} \rightarrow 2 \mathrm{R}-\mathrm{COO}^{-}+\mathrm{CH}_{3} \mathrm{COO}^{-}+\mathrm{H}^{+}+2 \mathrm{H}_{2} \mathrm{O}$

$2 \mathrm{R}-\mathrm{CH}_{2} \mathrm{OH}+\mathrm{HCO}_{3}^{-} \rightarrow 2 \mathrm{R}-\mathrm{COO}^{-}+\mathrm{CH}_{4}+\mathrm{H}^{+}+\mathrm{H}_{2} \mathrm{O}$. 
Table 1. Substrates tested for growth of alcohol fermenting strains of Acetobacterium carbinolicum compared with $A$. woodii and $A$. wieringae. Growth tests were carried out in defined medium, with $A$. wieringae in the presence of $0.1 \%$ yeast extract

\begin{tabular}{|c|c|c|c|c|}
\hline \multirow[t]{2}{*}{$\begin{array}{l}\text { Substrate } \\
\text { degraded }\end{array}$} & \multicolumn{2}{|c|}{$\begin{array}{l}\text { A. carbinolicum } \\
\text { strain }\end{array}$} & \multirow[t]{2}{*}{$\begin{array}{l}A . \\
\text { woodii }^{\mathbf{a}}\end{array}$} & \multirow[t]{2}{*}{$\begin{array}{l}\text { A. } \\
\text { wieringae }^{\mathrm{b}}\end{array}$} \\
\hline & WoProp1 & OttEtOH1 & & \\
\hline $\mathrm{H}_{2} / \mathrm{CO}_{2}$ & + & + & + & + \\
\hline Formate & + & + & + & + \\
\hline Methanol & + & - & $+^{\mathfrak{c}}$ & - \\
\hline $\begin{array}{l}\text { 3,4,5-Trimethoxy- } \\
\text { benzoic acid } \\
\text { 3,4,5-Trimethoxy- }\end{array}$ & + & + & $t^{c}$ & $-{ }^{d}$ \\
\hline $\begin{array}{c}\text { cinnamic acid } \\
\text { cinte }\end{array}$ & + & + & $+^{\mathrm{c}}$ & $-d$ \\
\hline Ethanol & + & + & - & - \\
\hline Propanol & + & + & - & $-{ }^{d}$ \\
\hline Butanol & + & + & - & $-d$ \\
\hline Pentanol & + & + & - & $-d$ \\
\hline Ethyleneglycol & + & + & + & $+{ }^{d}$ \\
\hline 1,2-Propanediol & + & + & $t^{d}$ & $+{ }^{d}$ \\
\hline 2,3-Butanediol & + & - & $t^{e}$ & $-d$ \\
\hline Acetoin & + & + & $+{ }^{\mathrm{e}}$ & $+d$ \\
\hline Glycerol & + & + & $+^{\mathrm{d}}$ & + \\
\hline Malate & - & - & - & - \\
\hline Lactate & + & + & \pm & + \\
\hline Pyruvate & + & - & + & - \\
\hline Glucose & + & - & $-{ }^{f}$ & - \\
\hline Fructose & + & - & + & + \\
\hline
\end{tabular}

\pm Means weak growth

a Data from Balch et al. 1977

b Data from Braun and Gottschalk 1982

- Data from Bache and Pfennig 1981

d Results of the present study

e Data from Schink 1984b

f Growth reported by Balch et al. (1977) could not be reproduced in our laboratory with strains DSM 1030 and NzVa16

ate as sole fermentation product. Methanol and methyl residues of methoxylated aromatic compounds were also fermented to acetate in a similar manner as observed with Acetobacterium woodii (Bache and Pfennig 1981), however, the double bond in cinnamic acid derivates was not reduced.

Among the homoacetogenic bacteria described so far, only Clostridium aceticum (Wieringa 1940; Adamse 1980; Braun et al. 1981) and C. formicoaceticum (Andreesen et al. 1970) are able to grow on ethanol, but higher alcohols are not utilized. Oxidation of 2,3-butanediol and acetoin was recently reported for $A$. woodii, C. aceticum, and C. magnum (Schink 1984b). Whereas most substrates were converted exclusively to acetate, oxidation of propanol, 1,2-propanediol, butanol, and pentanol by the new isolates led to formation of propionate, butyrate, and valerate, respectively, together with acetate which was formed as reduced fermentation product from carbon dioxide. Thus, homoacetogenesis should no longer be misinterpreted as a process in which acetate is the only end product; depending on the nature of the substrates, incomplete oxidation may lead to other products. Already the demethoxylation of methoxylated aromatic acids by $A$. woodii (Bache and Pfennig 1981) was, strictly speaking, such an incomplete oxidation. The basic property of all homoacetogenic bacteria is their ability to use carbon dioxide as inorganic electron acceptor, an ability which allows these bacteria to

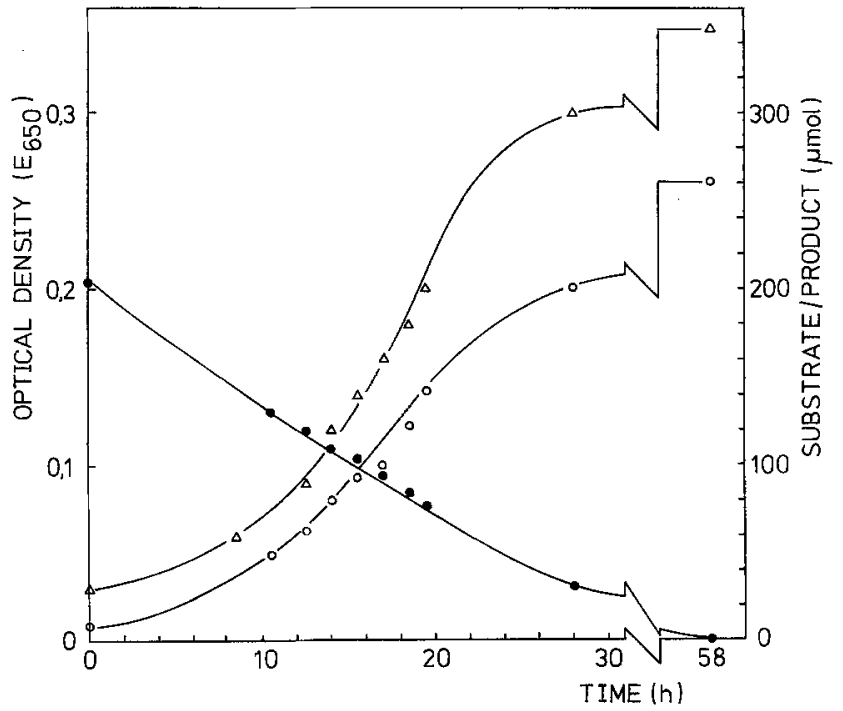

Fig. 3. Fermentation time course of Acetobacterium carbinolicum strain WoProp1 degrading ethanol. Experiments were performed at $28^{\circ} \mathrm{C}$ in $20 \mathrm{ml}$ tubes sealed with butyl rubber septa. Samples were removed with a syringe at times indicated, and the headspaces were flushed with $\mathrm{N}_{2} / \mathrm{CO}_{2}$ gas mixture. Symbols $\triangle$ cell density; - ethanol degraded; $O$ acetate formed. $\mathrm{E}_{650}$, optical density at $650 \mathrm{~nm}$

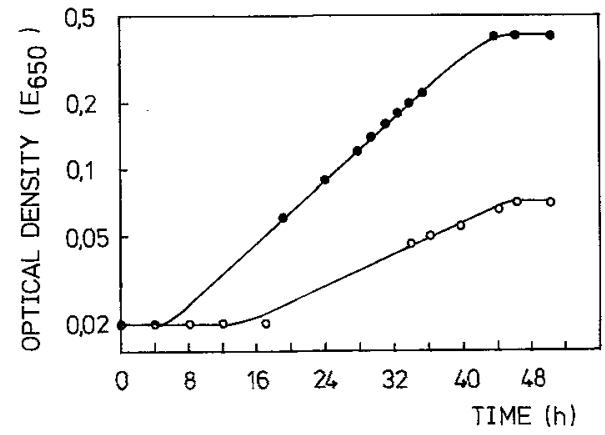

Fig. 4. Influence of $\mathrm{H}_{2}$ on ethanol degradation by Acetobacterium carbinolicum strain WoProp1. Experimental conditions as described in Fig. 3. The medium contained $10 \mathrm{mmol} / 1$ ethanol and $0.05 \%$ yeast extract. Symbols growth under $\mathrm{N}_{2} / \mathrm{CO}_{2} ; \mathrm{O}$ growth under $\mathrm{H}_{2} / \mathrm{CO}_{2} . \mathrm{E}_{650}$, optical density at $650 \mathrm{~nm}$

grow on a variety of reduced fermentation products and to use readily fermentable substrates (e.g. sugars) more efficiently than other fermenting anaerobes. We therefore basically agree with the principles Andreesen et al. (1970) formulated for homoacetogenic fermentations: that (1) three mol of acetate have to be formed from hexoses, (2) no (or only little) molecular hydrogen is formed, (3) carbon dioxide is necessary for growth and (4) carbon dioxide is incorporated into both carbon atoms of acetate, depending on the kind of substrate used. Coculture experiments with the new isolates and Methanospirillum hungatei demonstrated that part of the electrons derived from alcohol oxidation can be transferred to the methanogen, probably as molecular hydrogen. The amount of electrons transferred varied with the chain length of the alcohol: butanol and pentanol gave rise to more methane formation than ethanol and propanol. Since growth on butanol and pentanol is by far slower than 
Table 2. Growth yields and stoichiometry of fermentation by Acetobacterium carbinolicum strain WoProp1

\begin{tabular}{|c|c|c|c|c|c|c|c|c|c|c|}
\hline \multirow[t]{2}{*}{ Substrate } & \multirow{2}{*}{$\begin{array}{l}\text { Amount } \\
\text { of sub- } \\
\text { strate } \\
\text { supplied } \\
(\mu \mathrm{mol})\end{array}$} & \multirow{2}{*}{$\begin{array}{l}\text { Optical } \\
\text { density } \\
\left(\mathrm{E}_{650}\right)\end{array}$} & \multirow{2}{*}{$\begin{array}{l}\text { Cell dry } \\
\text { weight } \\
\text { formed }^{\mathrm{a}} \\
(\mathrm{mg})\end{array}$} & \multirow{2}{*}{$\begin{array}{l}\text { Acetate } \\
\text { assimi- } \\
\text { lated }^{\mathbf{b}} \\
(\mu \mathrm{mol})\end{array}$} & \multicolumn{4}{|c|}{ Products formed $(\mu \mathrm{mol})$} & \multirow{2}{*}{$\begin{array}{l}\text { Growth } \\
\text { yield } \\
\text { (g per mol } \\
\text { substrate } \\
\text { utilized) }\end{array}$} & \multirow{2}{*}{$\begin{array}{l}\text { Carbon } \\
\text { recovery } \\
(\%)\end{array}$} \\
\hline & & & & & Acetate & Propionate & Butyrate & Valerate & & \\
\hline $\mathrm{H}_{2} / \mathrm{CO}_{2}$ & 400 & 0.12 & 0.27 & 5.5 & 90.0 & - & - & - & 0.675 & 95.6 \\
\hline Formate & 400 & 0.20 & 0.98 & 20.2 & 76.2 & - & - & - & 2.45 & 96.4 \\
\hline Methanol & 100 & 0.17 & 0.82 & 16.9 & 62.4 & $-\cdot$ & - & - & 8.20 & 105.7 \\
\hline $\begin{array}{l}\text { 3,4,5-Trimethoxy- } \\
\text { benzoic acid } \\
\text { 3,4,5-Trimethoxy- }\end{array}$ & 50 & 0.24 & 1.16 & 23.9 & 80.2 & - & - & - & 23.2 & 94.6 \\
\hline cinnamic acid & 50 & 0.31 & 1.50 & 30.9 & 79.0 & - & - & - & 30.0 & 99.9 \\
\hline Ethanol & 200 & 0.23 & 1.11 & 22.9 & 279.2 & - & - & - & 5.55 & 100.7 \\
\hline Propanol & 200 & 0.21 & 1.02 & 20.9 & 81.3 & 195.2 & - & - & 5.10 & 99.1 \\
\hline Butanol & 200 & 0.16 & 0.77 & 15.9 & 86.5 & - & 197.4 & - & 3.85 & 100.0 \\
\hline Pentanol & 200 & 0.18 & 0.87 & 17.9 & 88.9 & - & - & 190.6 & 4.35 & 99.1 \\
\hline Ethyleneglycol & 200 & 0.25 & 1.21 & 24.9 & 227.7 & - & - & - & 6.05 & 101.1 \\
\hline 1,2-Propanediol & 200 & 0.29 & 1.40 & 28.9 & 22.3 & 192.7 & - & - & 7.00 & 97.6 \\
\hline 2,3-Butanediol & 200 & 0.36 & 1.74 & 35.8 & 502.0 & - & - & - & 8.71 & 97.8 \\
\hline Acetoin & 200 & 0.50 & 2.42 & 49.8 & 460.0 & - & - & - & 12.10 & 102.0 \\
\hline Glycerol & 200 & 0.26 & 1.26 & 25.9 & 321.4 & - & - & - & 6.30 & 99.2 \\
\hline Lactate & 200 & 0.30 & 1.43 & 29.5 & 276.6 & - & - & - & 7.14 & 102.0 \\
\hline Pyruvate & 200 & 0.31 & 1.50 & 30.9 & 177.0 & - & - & - & 7.50 & 83.2 \\
\hline Glucose & 50 & 0.50 & 2.42 & 49.9 & 106.0 & - & - & - & 48.4 & 103.9 \\
\hline Fructose & 40 & 0.37 & 1.80 & 37.1 & 91.4 & - & - & - & 45.0 & 85.7 \\
\hline
\end{tabular}

Experiments were carried out in $20 \mathrm{ml}$ tubes which were completely filled. Growth on $\mathrm{H}_{2} / \mathrm{CO}_{2}$ was tested in half-filled tubes under an atmosphere of $80 \% \mathrm{H}_{2} / 20 \% \mathrm{CO}_{2}$

a Cell dry weights were calculated via cell density using the conversion factor $0.1 \mathrm{OD}_{650} \cong 24.2 \mathrm{mg}$ dry weight per 1 , which was obtained by direct determination in $500 \mathrm{ml}$ cultures grown with ethanol

b Substrate assimilated was calculated using the formula $\left(\mathrm{C}_{4} \mathrm{H}_{7} \mathrm{O}_{3}\right)$ for cell material

- Carbon recovery in pure cultures was calculated after the given equations of fermentation

Table 3. Growth yields and stoichiometry of fermentation by Acetobacterium carbinolicum strain WoProp1 in coculture with Methanospirillum hungatei

\begin{tabular}{|c|c|c|c|c|c|c|c|c|}
\hline Substrate & $\begin{array}{l}\text { Substrate } \\
\text { supplied } \\
(\mu \mathrm{mol})\end{array}$ & Acetate & Propionate & Butyrate & Valerate & Methane & $\begin{array}{l}\text { Growth } \\
\text { yield } \\
(\mathrm{g} / \mathrm{mol})\end{array}$ & $\begin{array}{l}\text { Carbon } \\
\text { recovery } \\
(\%)\end{array}$ \\
\hline Ethanol & 200 & 262 & - & - & - & 27 & 8.62 & 96.3 \\
\hline Propanol & 200 & 70 & 189 & - & - & 27 & 8.62 & 95.3 \\
\hline Butanol & 200 & 59 & - & 191 & - & 49 & 7.71 & 99.7 \\
\hline Pentanol & 200 & 61 & - & - & 189 & 51 & 7.41 & 100.3 \\
\hline
\end{tabular}

Experiments were carried out in half-filled $50 \mathrm{ml}$ serum bottles, headspaces gassed with $\mathrm{N}_{2} / \mathrm{CO}_{2}$ gas mixture $(80 \% / 20 \%)$

Calculation of yields and carbon recovery as described in Table 2

on ethanol or propanol, the methanogens appear to be more efficient in hydrogen scavenging in slow-growing systems than in fast ones. This observation is of importance with respect to natural environments: since subtrate turnover is much slower there than in laboratory cultures, homoacetogenic bacteria may act in nature as syntrophic partners of methanogens to a higher extent and with more substrates than expected so far (Winter and Wolfe 1979, 1980). Excess hydrogen added to pure cultures delayed and inhibited growth on ethanol considerably. Similar observations were made with $A$. woodii and $C$. aceticum growing on fructose (Braun and Gottschalk 1981) and can be explained as due to a shift in the redox state of cell-internal electron carriers. Thus, externally provided hydrogen inhibits ethanol oxidation not only in syntrophic mixed cultures but also in homoacetogenic pure cultures. Inhibition of ethanol degradation by hydrogen was recently demonstrated in sediments of Knaack Lake, an environment in which homoacetogenic bacteria similar to our isolates seem to be responsible for the bulk of ethanol degradation (Schink et al. 1985).

\section{Taxonomy}

The new bacteria described are typical homoacetogenic bacteria forming acetate as reduced end product either from organic substrates or from $\mathrm{H}_{2} / \mathrm{CO}_{2}$ or formate. Although they are physiologically similar to Clostridium aceticum they cannot be classified with this genus since they do not form spores. Morphological, cytological and most physiological properties are very similar to those of Acetobacterium woodii. 
They have nearly identical $\mathrm{G}+\mathrm{C}$-contents of the DNA and contain murein of the same crosslinkage type B (Kandler and Schoberth 1979; Kandler, personal communication). The most significant difference of the new strains compared to $A$. woodii and $A$. wieringae (Braun and Gottschalk 1982) is their capacity to oxidize primary aliphatic alcohols to the respective fatty acids and acetate. For this reason, the described isolates are attributed to the genus Acetobacterium as a new species, $A$. carbinolicum.

\section{A. carbinolicum sp. nov.}

car. bi. no' li. cum M. L. adj. referring to carbinols syn. alcohols. carbinolicum metabolizing alcohols.

Rod-shaped cells, $0.8-1.0 \times 1.5-2.5 \mu \mathrm{m}$, with slightly pointed ends, single or in pairs. Motile. No spore formation. Gram-positive.

Chemoorganotroph or autotroph. Methanol, ethanol, 2,3-butanediol, acetoin, glycerol, lactate, pyruvate, glucose, fructose as well as methyl groups of methoxylated aromatic compounds and betaine utilized for growth and fermented to acetate. Propanol, butanol, pentanol and 1,2-propanediol fermented to the corresponding fatty acids and acetate.

Autotrophic growth on formate and $\mathrm{H}_{2} / \mathrm{CO}_{2}$; acetate formed. Sulfate, thiosulfate, elemental sulfur, or nitrate not reduced. No cytochromes.

Strictly anaerobic. Growth requires mineral medium with less than $0.7 \%(\mathrm{w} / \mathrm{v}) \mathrm{NaCl}$ and $0.15 \%(\mathrm{w} / \mathrm{v})$ $\mathrm{MgCl}_{2} \cdot 6 \mathrm{H}_{2} \mathrm{O}$.

pH-range: $6.0-8.0$, optimum at 7.0.

Temperature-range: $15^{\circ} \mathrm{C}-40^{\circ} \mathrm{C}$, optimum at $27^{\circ} \mathrm{C}$.

DNA base ratio $38.5 \mathrm{~mol} \% \pm 1.0 \% \mathrm{G}+\mathrm{C}$.

Habitats: anoxic muds of freshwater origin.

Type strain: WoProp1, DSM 2925; deposited in Deutsche Sammlung von Mikroorganismen, Göttingen, FRG.

Acknowledgements. The autors are indebted to Prof. Dr. N. Pfennig for support and valuable criticism, to Dr. Walther Johannssen, Göttingen, for electron microscopic characterization, and to Prof. Dr. Otto Kandler, München, for analysis of murein chemistry. This work was supported by research funds of the Universität Konstanz.

\section{References}

Adamse AD (1980) New isolation of Clostridium aceticum (Wieringa). Antonie van Leeuwenhoek J Microbiol Serol 46: $523-531$

Andreesen JR, Gottschalk G, Schlegel HG (1970) Clostridium formicoaceticum nov. spec. Isolation, description and distinction from C. aceticum and C. thermoaceticum. Arch Mikrobiol $72: 154-174$

Bache R, Pfennig N (1981) Selective isolation of Acetobacterium woodii on methoxylacted aromatic acids and determination of growth yields. Arch Microbiol 130:255-261

Balch WE, Schoberth S, Tanner RS, Wolfe RS (1977) Acetobacterium, a new genus of hydrogen-oxidizing, carbon-dioxidereducing, anaerobic bacteria. Int J Syst Bacteriol 27:355-361

Barker HA (1941) Studies on the methane fermentation. V. Biochemical activities of Methanobacterium omelianskii. J Biol Chem 137:153-167

Bornstein BT, Barker HA (1948) The nutrition of Clostridium kluyveri. J Bacteriol 55:223-230
Braun K, Gottschalk G (1981) Effect of molecular hydrogen and carbon dioxide on chemo-organotrophic growth of Acetobacterium woodii and Clostridium aceticum. Arch Microbiol 128:294-298

Braun M, Gottschalk G (1982) Acetobacterium wieringae sp. nov., a new species producing acetic acid from molecular hydrogen and carbon dioxide. Zbl Bakt Hyg, I Abt Orig C3:368-376

Braun M, Mayer F, Gottschalk G (1981) Clostridium aceticum (Wieringa) a microorganism producing acetic acid from molecular hydrogen and carbon dioxide. Arch Microbiol 125:288-293

Bryant MP, Wolin EA, Wolin MJ, Wolfe RS (1967) Methanobacillus omelianskii, a symbiotic association of two species of bacteria. Arch Mikrobiol 59:20-31

Hollaus F, Sleytr U (1972) On the taxonomy and fine structure of some hyperthermophilic saccharolytic clostridia. Arch Mikrobiol 86:129-146

Kandler O, Schoberth S (1979) Murein structure of Acetobacterium woodii. Arch Microbiol 120:181-183

Laanbroek HJ, Abee T, Voogd JL (1982) Alcohol conversions by Desulfobulbus propionicus Lindhorst in the presence and absence of sulfate and hydrogen. Arch Microbiol 133:178-184

Pfennig N (1978) Rhodocyclus purpureus gen. nov. and sp. nov., a ring-shaped, vitamin $B_{12}$-requiring member of the family Rhodospirillaceae. Int J Syst Bacteriol 23:283-288

Postgate JR, Campbell LL (1966) Classification of Desulfovibrio species, the nonsporulating sulfate-reducing bacteria. Bacteriol Rev 30:732-738

Samain E, Albaniac G, Dubourgier HC, Touzel JP (1982) Characterization of a new propionic acid bacterium that ferments ethanol and displays a growth factor dependent association with a Gram-negative homoacetogen. FEMS Microbiol Lett 15:69-74

Schink B (1984a) Fermentation of 2,3-butanediol by new strains of Gram-negative, non-sporing anaerobes, Pelobacter carbinolicus sp. nov. and Pelobacter propionicus sp. nov. and evidence for formation of propionate from $\mathrm{C}_{2}$ compounds. Arch Microbiol $137: 33-41$

Schink B (1984 b) Clostridium magnum sp. nov., a non-autotrophic homoacetogenic bacterium. Arch Microbiol 137:250-255

Schink B, Pfennig N (1982) Fermentation of trihydroxybenzenes by Pelobacter acidigallici gen. nov. sp. nov., a new strictly anaerobic, non-sporeforming bacterium. Arch Microbiol 133:195-201

Schink B, Phelps TJ, Eichler B, Zeikus JG (1985) Comparison of ethanol degradation pathways in anoxic freshwater environments. J Gen Microbiol (submitted)

Tschech A, Pfennig N (1984) Growth yield increase linked to caffeate reduction in Acetobacterium woodii. Arch Microbiol 137:163-167

Widdel F, Pfennig N (1981) Studies on dissimilatory sulfate-reducing bacteria that decompose fatty acids. I. Isolation of new sulfate-reducing bacteria enriched with acetate from saline environments. Description of Desulfobacter postgatei gen. nov. sp. nov. Arch Microbiol 129:395-400

Wieringa KT (1940) The formation of acetic acid from carbon dioxide and hydrogen by anaerobic spore-forming bacteria. Antonie van Leeuwenhoek J Microbiol Serol 6:251-262

Winter J, Wolfe RS (1979) Complete degradation of carbohydrate to carbon dioxide and methane by syntrophic cultures of Acetobacterium woodii and Methanosarcina barkeri. Arch Microbiol 121:97-102

Winter J, Wolfe RS (1980) Methane formation from fructose by syntrophic associations of Acetobacterium woodii and different strains of methanogens. Arch Microbiol 124:73-79

Received August 8, 1984/Accepted August 19, 1984 